\title{
自然災害リスクの指標化
}

\section{How to quantify natural disaster risk}

保田敬一 Keiichi YASUDA
(社) 国際建設技術協会

Infrastructure Development Institute-JAPAN

Keywords : National resilience, Maintenance, Natural disaster, Risk

\section{1. はじめに}

インフラレジリエンスを理解するにあたり，自然災害リスクの 観点は避けては通れない，一般市民にとって社会インフラへの 自然災害リスクの影響という話になると専門用語ばかりで理解 しづらいことが多い. 我が国は自然災害多発国ではあるが, 地域によって自然災害リスクが高い, 低いという差が生じている ことも事実である. 地域住民にとっても維持管理者にとっても, 自身の住んでいる地域がどの程度の自然焱害リスクを保有し ているのかを把握しておくことは重要である。自然災害リスク の算定には脆弱性, 曝露量, レジリエンスなどの指標が関係し ているが, 本稿ではこれらの用語について感性的な観点から 説明を加え, 少しでも理解してもらえるようなきっかけとしたい.

\section{2. 自然災害リスク評価方法}

自然災害リスクを定量的に示したものには，世界リスク指標 （WRI：World Risk Index）[1] がある。また，国内向けには， 自然災害安全性指標（GNS：Gross National Safety for natural disasters）[2,3]市り，これまで, GNS 2015 [4]抽よ゙ GNS 2017 [5] が公開されている. インフラ維持管理で適用 される自然災害リスクもあわせてこれらの対比を表1に示す。 本項ではインフラの対象は橋梁とし, 維持管理で適用される 自然災害リスク算出体系を図 1 に示す.

本稿では, WRIやGNSのように脆弱性の中に対処能力 や適応能力を含めるのではなく，対処能力や適応能力はあく まで事後対応なのでレジリエンスの範疇であると考えた。 また, 脆弱性は弱さのことなので, その構造物が保有して いる劣化のし易さ, 保有耐力の程度, 使用環境の悪さなどを
取り扱うものと考えた。すなわち，脆弱性とレジリエンスと は別物であるとした方が理解しやすいと考えた。

\section{3. 自然災害リスクの算定}

\section{1 曝露量}

\section{（1）算定方法}

曝露とはある特定の問題となる因子に集団あるいは個人と いった生体がさらされることをいい，さらされている量を曝露 量 (Exposure) という。ここでいう問題となる因子とは微生物, 化学物質, 薬物, 環境污染物質, その他有害物質をさすこと が多い。この問題の因子を自然災害に置き換えてみると, 自然災害に対して日本国民（地域住民）がさらされている程度 を曝露量として定義することになる，自然贸害の規模が小さい 場合はほとんど被害は受けないが, 大規模自然災害が発生し た際は避難，施設倒壊などの被害をうけることになる。この

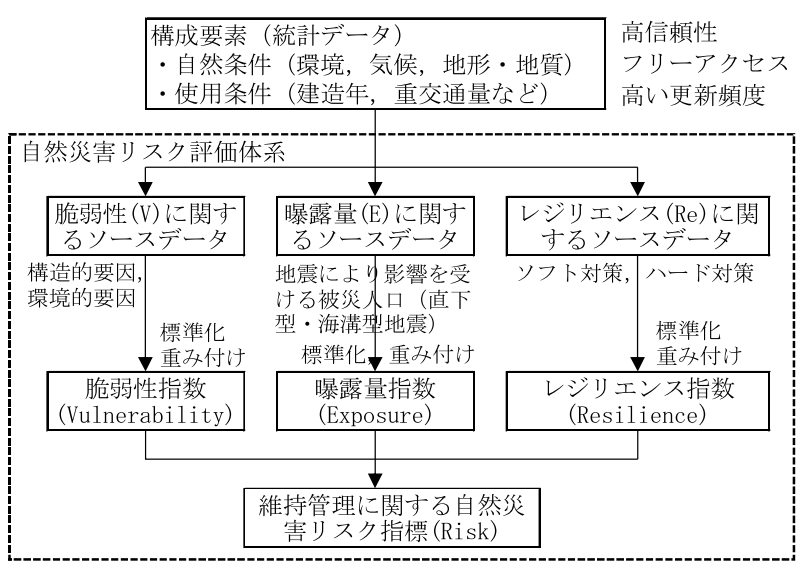

図1 自然災害リスク指標算出体系

表1 インフラ維持管理における自然災害リスク指標, GNS, WRI との違い

\begin{tabular}{|c|c|c|c|}
\hline & $\begin{array}{l}\text { 橋梁維持管理における } \\
\text { 自然災害リスク指標 } \\
\end{array}$ & $\begin{array}{l}\text { GNS (Gross National Safety for } \\
\text { natural disasters: GNS) }\end{array}$ & WRI（World Risk Index） \\
\hline 目的 & $\begin{array}{l}\text { 維持管理計画への自然災害リスクの関係度合い } \\
\text { と,, 防災減災機能をどの程度維持管理計画に反 } \\
\text { 映していくがを判断するた少のの摽 }\end{array}$ & $\begin{array}{l}\text { 自然災害リスクを定量的に示した防災 } \\
\text { 減災投資の意思決定者へ向けた指標 }\end{array}$ & $\begin{array}{l}\text { 世界171 か国の自然災害リスクを示し } \\
\text { たもの. }\end{array}$ \\
\hline 定義 & $\begin{array}{l}\text { 自然災害リスク } \mathrm{R}=\mathrm{f}(\mathrm{E}, \mathrm{V}, \mathrm{Re}) \\
\mathrm{E}: \text { 暴露量, } \mathrm{V}: \text { 脆弱性, } \mathrm{Re}: \text { レジリエンス }\end{array}$ & $\begin{array}{l}\text { 自然焱害リスク } \mathrm{R}=\mathrm{f}(\mathrm{H}, \mathrm{E}, \mathrm{V}) \\
\mathrm{H}: \text { 災害発生頻度, } \mathrm{E} \text { : 人口割合 }(\mathrm{H} \cdot \mathrm{E} を \\
\text { 暴露量と定義), } \mathrm{V} \text { : 脆弱性 (ハード対策 } \\
\text { ×ソフト対策) }\end{array}$ & $\begin{array}{l}\text { 自然災害リスク } \mathrm{R}=\mathrm{f}(\mathrm{E}, \mathrm{V}) \\
\mathrm{E} \text { : 暴露量, } \mathrm{V}: \text { 脆弱性 }(=(\mathrm{S}+\mathrm{C}+\mathrm{A}) / 3)\end{array}$ \\
\hline $\begin{array}{l}\text { 利用 } \\
\text { 方法 }\end{array}$ & $\begin{array}{l}\text { 都道府県別に自然災害リスクおよび脆弱性を明 } \\
\text { 示することで管理機の今後の維持管理計画に } \\
\text { おいての防災投資への判断指標の一つとなる。 }\end{array}$ & $\begin{array}{l}\text { 都道府県別に自然災害リスクを明示す } \\
\text { ることで, 管理機の関の今後の防災投資 } \\
\text { への判断指標の一となる. }\end{array}$ & $\begin{array}{l}\text { 自国が世界的にどのぐらいの順位にい } \\
\text { るのかを知ることができる. }\end{array}$ \\
\hline
\end{tabular}


被害をうけるということを自然災害にさらされていると同意に 考える. 沢山の人が被害をうければさらされている程度は大き いと考える. さらされている程度を人数と仮定すると, ある䦨 值以上の規模の自然災害に対して被害を被る人数が曝露量で あると説明できる。 もう少し具体的にいうと，隣接するA地域, B 地域があったとして, ある自然災害が発生した際, A 地域の 方が人数が多ければ曝露量は $\mathrm{A}$ 地域の方が多いと判断できる.

インフラの維持管理においては, 世界リスク指標 (WRI)や GNSにて考慮している多くの自然災害は対象としていない. すなわち, 複数の災害の種類 (地震, 津波, 高潮, 土砂災害, 火山噴火)の中でも発生時に橋梁の倒壊, 損傷発生など維持 管理において最も影響すると思われる地震だけを対象とした。 地震には海溝型地震と直下型地震の2種類がある. 海溝型 地震については, 国立研究開発法人 防災科学技術研究所の J-SHIS MAPにある被災人口地図を使用して算出した。海溝 型地震は, J-SHISにて想定されている12の地震 (北海道南 西沖地震, 北海道西方沖地震, 南海卜ラフ地震, 東北地方太 平洋沖地震, 相模卜ラフ沿地震, 千島海溝沿地震, 青森県西 方沖地震, 新潟県北部沖地震, 十勝沖プレート間地震, 山形 県沖地震, 三陸沖北部のプレート間大地震, 根室沖プレート 間地震) とした。これらの地震による震度 6 弱以上の震度曝 露人口を都道府県別に集計して海溝型地震の暴露量とした。

直下型地震については, 活断層の延長距離を使用した。 GNS と同様の考え方により活断層の延長を都道府県の面積で 除することにより都道府県全体への影響のし易さを考慮した。 これは都道府県別の活断層密度を算定していることになる. 活断層の延長は国立研究開発法人 産業技術総合研究所の 活断層データベースから算定した。

\section{(2) 算定結果}

前節にて示した算定方法により，曝露量に係る要因ごとに指 標を算出した。 曝露量は海溝型地震による被災人口と活断層 密度の平均から算出される，被災人口 (e1) と活断層密度 (e2) の平均值による曝露量 $(\mathrm{E})$ を都道府県ごとに $0 \sim 1$ で指標化し たマップを図2に示す.

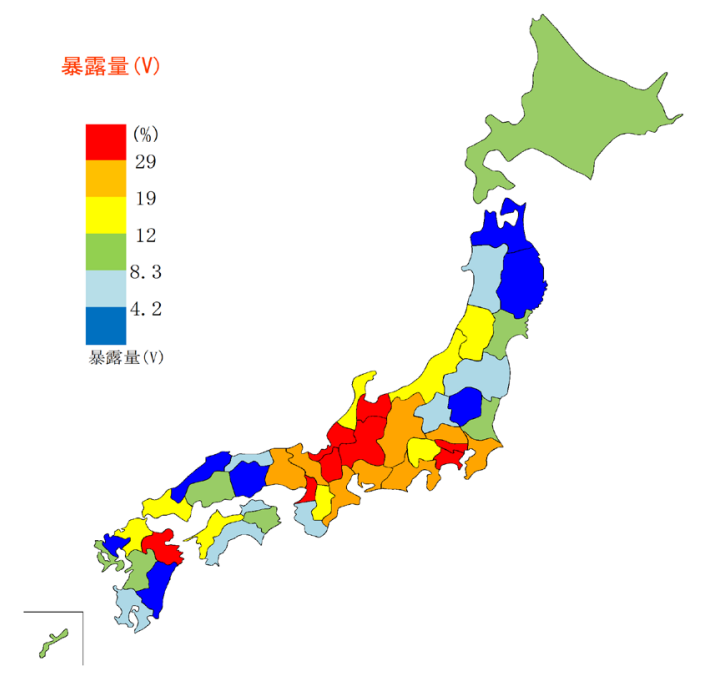

図2 曝露量の都道府県分布 [6]
曝露量が最も高いのは東京都，次に高いのは大阪府，次が 福井県, 大分県, 神奈川県, 富山県, 岐阜県, 滋賀県, 愛知 県の順である. 曝露量の最も小さいのは佐賀県, 次に小さい のが宮崎県, 次が島根県, 青森県, 岡山県, 栃木県, 岩手県, 群馬県の順になる。東京都は被災人口の值が全国でも突出し ており，活断層密度は全国でも33位であるが, e1 と e2の 平均值となるとどうしても上位にくることになる，東京への 人口一極集中の弊害が指摘される結果となる.

\section{2 脆弱性}

\section{（1）算定方法}

脆弱性 (Vulnerability) とは, 適用される技術分野によって 意味が異なるが, 一般的に広く知られているのは情報通信用 語のことをいい, コンピュータのOSやソフトウェアにおいて, プログラムの不具合や設計上のミスが原因となって発生した 情報セキュリティ上の欠陥（セキュリテイホールともいう）のこ とをいう.

脆弱性を社会インフラに適用した場合，インフラ自体の欠陥 というよりも使用条件や環境条件が変わった場合に該当する 構造物の耐力や安全性が低下する場合, 脆弱性が高いという 表現をする。 日本は脆弱性の高い国土という表現を良く用い るが, これは大規模な台風や巨大地震によって構造物の被害, 土砂災害, 河川の氾濫などが多く発生するためである.

橋梁の維持管理においての脆弱性は構造的要因と環境的 要因に区分できる。それぞれの要因の考え方と使用デー夕を 表2 に示す.

構造的要因 $(S)$ は式 (1)にて, 環境的要因 (E) は式 (2)に て算出し, 脆弱性は $S$ と $E$ の平均值を採用する.

$$
\begin{aligned}
& S=\frac{s 1+s 2+s 3+s 4+s 5}{5} \\
& E=\frac{e 1+e 2+e 3}{3}
\end{aligned}
$$

ここに, $s 1$ : 橋の平均年齢, $s 2$ : 橋の平均年齢の将来推移, $s 3$ : 橋の数, $s 4$ : 特殊形式橋梁の割合, $s 5$ : 耐震補強進渉率 である. $e 1$ : 規模の大きい地震の受けやすさ, $e 2$ : 重交通量, $e 3$ : 塩害影響度合い(海岸線の延長と冬期最低温度の指標の 平均值)である.

\section{(2) 算定結果}

構造的要因と環境的要因とで構成される脆弱性を都道府県 ごとに0〜1で指標化したマップを図3に示す.

総合的脆弱性 $(\mathrm{V})$ で值が高いのは, 北海道, 東京都, 長野 県, 愛知県, 兵庫県, 神奈川県, 三重県の順になっている. 逆に, 総合的脆弱性 (V) で值が低いのは, 沖縄県, 島根県, 青森県, 鳥取県, と徳島県, 香川県の順になっている。北海道 は構造的脆弱性 (S) が全国 1 位で, 環境的脆弱性 (E) も全国 3位と両者ともに脆弱性がかなり高い，東京都は，構造的脆 弱性 (S) は全国19位であるが, 環境的脆弱性 (E) が全国1位 となっている. 愛知県は, 構造的脆弱性 $(\mathrm{S})$ は全国13位で あるが, 環境的脆弱性 (E) が全国5位となっている。ここで 


\section{表2 脆弱性を構成する要因の考え方と使用データ}

\begin{tabular}{|c|c|c|c|}
\hline & 要因 & 考え方 & 使用デー夕 \\
\hline \multirow{5}{*}{ 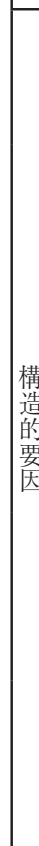 } & $\begin{array}{l}\text { 橋の平均年 } \\
\text { 齢 (老朽化 } \\
\text { 率) }\end{array}$ & $\begin{array}{l}\text { 建造後 } 50 \text { 年を超える橋の割合と } \\
\text { L, この割合が高い方が将来補 } \\
\text { 修·改築する可能性が高く, 脆弱 } \\
\text { 性が高いと判断する. }\end{array}$ & $\begin{array}{l}\text { WEB頁で公開されて } \\
\text { いる各都道府県の橋 } \\
\text { 梁長寿命化修繕計画 } \\
\text { に記載されたデー夕 }\end{array}$ \\
\hline & \begin{tabular}{|} 
橋平均年齢 \\
の将来推移
\end{tabular} & $\begin{array}{l}\text { 劣化進行度合いを表現するため } \\
\text { に建造後 } 50 \text { 年を超える橋の割合 } \\
\text { が今後どのように推移するか } \\
\text { (年間割合の推移)で表し, この } \\
\text { 割合が高い方が将来補修・改築 } \\
\text { する可能性が高く脆弱性が高い } \\
\text { と判断する. }\end{array}$ & $\begin{array}{l}\text { 各都道府県橋梁長寿 } \\
\text { 命化修繕計画に記載 } \\
\text { されている将来推移か } \\
\text { こ比例計算にて算出 }\end{array}$ \\
\hline & 橋の数 & $\begin{array}{l}\text { 橋の数が多いとそれだけ管理す } \\
\text { るための資源 (人, 物, 金)が多く } \\
\text { かかるため脆弱性が高いと判断 } \\
\text { する. }\end{array}$ & $\begin{array}{l}\text { 全国 47都道府県の } \\
\text { 橋梁長寿命化修繥計 } \\
\text { 画に記載のある橋長 } \\
2 \mathrm{~m} \text { 以上の橋の数 }\end{array}$ \\
\hline & \begin{tabular}{|l|} 
特殊形式橋 \\
梁の割合
\end{tabular} & $\begin{array}{l}\text { 特殊形式の橋が全体に占める割 } \\
\text { 合で表す. 特殊形式の橋は点検 } \\
\text { や補修にも時間と費用がかかるた } \\
\text { め, この数が多いと脆弱性が高 } \\
\text { いと判断する. }\end{array}$ & $\begin{array}{l}\text { 国土交通省が公開し } \\
\text { ている構造形式別都 } \\
\text { 道府県別橋梁の現状 } \\
<\text { 国·都道府県道 }>\text { か } \\
\text { ら引用 }\end{array}$ \\
\hline & \begin{tabular}{|l} 
耐震補強進 \\
渉率
\end{tabular} & $\begin{array}{l}\text { 耐震補強を確実に行うことで構 } \\
\text { 造物の持つ脆弱性は格段に改善 } \\
\text { される. 耐震補強進渉率が低い } \\
\text { と脆弱性が高いと判断する. }\end{array}$ & $\begin{array}{l}\text { 緊急輸送道路 (都道府 } \\
\text { 県·政令市管理道路) } \\
\text { の耐震補強進渉率 } \\
\text { (H30年3月末末時点) } \\
\text { から引用 }\end{array}$ \\
\hline \multirow{3}{*}{$\begin{array}{l}\text { 環 } \\
\text { 境 } \\
\text { 的 } \\
\text { 要 }\end{array}$} & \begin{tabular}{|} 
大規模地震 \\
の受け易さ
\end{tabular} & $\begin{array}{l}\text { 道路橋示方書·耐震設計編では } \\
\text { 都道府県ごとに地震危険度の } \\
\text { 地域特性を反映しておうり, ランク } \\
\text { が高い方が脆弱性が高いと判断 } \\
\text { する. }\end{array}$ & $\begin{array}{l}\text { 地域別地震発生は, } \\
\text { 道路橋示方書·耐震設 } \\
\text { 計編に記載の地域区 } \\
\text { 分から引用 }\end{array}$ \\
\hline & 重交通量 & $\begin{array}{l}\text { 耐久性に影響する劣化因子であ } \\
\text { る疲労を考えた場合, 重交通の影 } \\
\text { 響が大きい. 重交通量が多い方 } \\
\text { が疲労に対する脆弱性が高いと } \\
\text { 判断する. }\end{array}$ & $\begin{array}{l}\text { 平成 } 27 \text { 年度全国道 } \\
\text { 路·街路交通情勢調査 } \\
\text { 一般交通量調査 集計 } \\
\text { 結果整理表より重交 } \\
\text { 通量を整理 }\end{array}$ \\
\hline & \begin{tabular}{|l} 
塩害影響度 \\
合い
\end{tabular} & 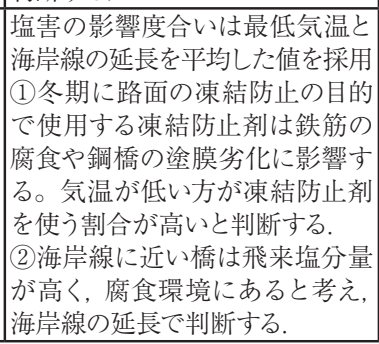 & $\begin{array}{l}\text { 1)最低気温での都道 } \\
\text { 府県ランング济 } \\
\text { (2)都府県別海岸線延 } \\
\text { 長から統計データを } \\
\text { 採用 }\end{array}$ \\
\hline
\end{tabular}

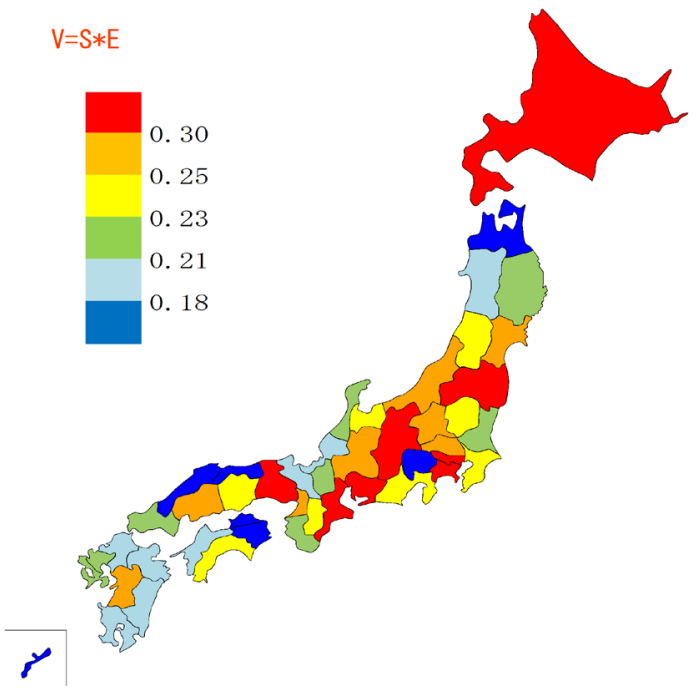

図3 脆弱性の都道府県分布 [7]
も脆弱性上位にくるのは大都市圈とその周辺地域，内陸部の 寒冷地である。構造的脆弱性 $(\mathrm{S})$ または環境的脆弱性 (E) が 上位 1 桁ランクの都道府県はこの総合的脆弱性でも上位ランク に属している。 なお，北海道は環境面および構造面でも両方と も脆弱性が高く, 特異な存在となっている. 沖縄県は構造的 脆弱性 (S) も環境的脆弱性 (E) もともに全国47位と最下位 となっている.

\section{3 レジリエンス}

\section{（1）算定方法}

レジリエンス(Resilience) とは,「回復力」,「弾性 (しなやかさ)」 を意味する用語で，状況が変わってもうまく適用できる力，自立的 に立ち直ることのできる強さ・柔軟性のことを指す，世界リスク 指標 (WRI) や自然災害安全性指標 (GNS) ではレジリエンス という直接の表現はして㧍らずレジリエンスは脆弱性に取り 込んだ形になっており, 対処能力や適応能力というレジリエンス と同義の指標を用いている，GNSではレジリエンスをハード 対策とソフト対策という，より具体的な形で表現している.

社会インフラに拝けるレジリエンスは自然災害に対する強勒 さの度合いを示すものとした，本項でもGNS と同様にソフト ウェア対策とハードウェア対策に分けて考えた，本項で考慮し たのは防災会議の開催頻度（開催回数を自治体の数で除して 算出する)，地域防災計画の策定揖よび被害想定の実施頻度 (開催回数を自治体の数で除して算出する), 防災訓練の参加 人数 (延べ), 震災対策啓発事業実施回数, 耐震貯水槽の 設置基数, 備蓄倉庫の設置棟数, 防災無線の設置数（地上固 定系と衛星固定系の合計数), 震災対策整備事業にかかる 費用の 8 項目である。都道府県実施分と市町村実施分の合計 をその都道府県の值とした，前述の項目ごとにその数が多い ほど発災後の回復度合いが早くなる, あるいは, 強勒さも 向上するため, レジリエンス性能が高くなると考えた。

一般的なレジリエンス対策である防災教育や防災会議の回 数, 防災施設の充実などは防災に係る人の意識を高め, 防災 意識を高く保持するという意味でもその回数や個数を多くする ほどレジリンス能力は高くなると考えた。防災訓練や防災会 議はその回数が多くなれば関係者間の防災意識が高くなる し, 耐震貯水槽, 非常時備蓄, 防災無線の数はその数が多い ほど非常時に扔いて平常時まで回復する時間が短縮できる, すなわち，レジリエンス性能が高くなると考えられる。

本稿ではレジリエンス $(\mathrm{Re})$ を式 (3)のように定義する.

$$
R e=\frac{\sum_{i=1}^{8} r i}{8}
$$

ここに, $R e$ (レジリエンス) $: r 1 \sim r 8$ の平均値, $r 1 ：$ 防災会 議の開催頻度, $r 2$ : 地域防災計画の策定挹よび被害想定の 実施頻度, $r 3$ : 防災訓練の参加人数, $r 4$ : 震災対策啓発事 業実施回数, $r 5$ : 耐震貯水槽の設置基数, $r 6$ : 備蓄倉庫の 設置棟数, $r 7$ : 防災無線の設置数, $r 8$ : 震災対策整備事業 にかかる費用である。 
採用した統計データは消防庁・地方防災行政の現状 (付 平成 29 年 災害年報)にある地域防災計画（震災対策編） の策定状況・調査結果表から引用した。

\section{(2) 算定結果}

前章にて示したレジリエンス算定方法にて指標を算定した。 レジリエンスはその值が高い方が強勒さが高い, あるいは 発災後の回復度合いが早いことを表している。レジリエンス を都道府県ごとに0〜1で指標化したマップを図4に示す.

レジリエンス指標の最も上位にくるのは東京都で, 次が 静岡県, 大阪府, 神奈川県, 愛知県, 千葉県, 北海道, 兵庫県, 滋賀県と続く，逆に，レジリエンス指標の最も小さいのは 福島県で, 次が秋田県, 青森県, 栃木県, 岩手県, 沖縄県, 鹿児島県, 山形県の順になる。ここでも人口とレジリエンス 指標との相関係数は 0.785 と高く, 強い相関関係にあることが わかる. レジリエンス指標の上位に大都市圈を含む都道府県 が抽出されていることからも相関があることが確認できる。

\section{4 自然災害リスク}

\section{（1）算定方法}

これまで説明してきた曝露量, 脆弱性およびレジリエンスを 組み合わせて自然倓害リスクを算定する。算定式を式 (4)に示す。

$$
R=E \cdot V \cdot(1-R e)
$$

ここに, $R$ : 自然災害リスク, $E$ : 曝露量, $V$ : 脆弱性, $R e:$ レシ リエンスである。

曝露量や脆弱性およびレジリエンスはその指標が高い方が リスクが高い方になることを意味している。レジリエンスは その数值が高い方が強勒さが高い, あるいは復旧からの回復 度合いが優れていることを意味するので, これはリスクが 低くなることと逆行する。よって，1からレジリエンスの 数值を減じることでレジリエンスに係る自然災害リスクとし て表現した， Reの数值が高い方が $(1-\mathrm{Re})$ の值は低くなり， 自然災害リスクに乗じるレジリエンスの項は低い值となる。

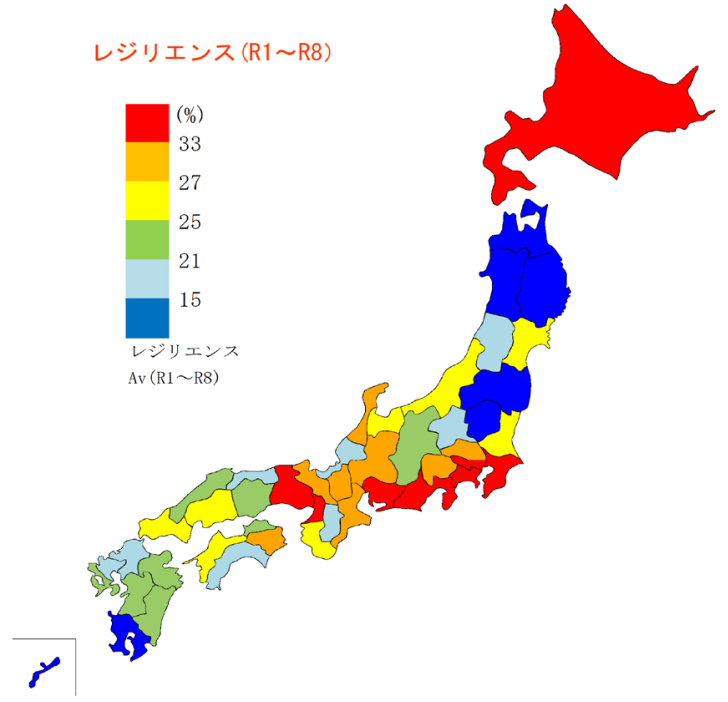

図4 レジリエンスの都道府県分布 [6]

\section{(2) 算定結果}

曝露量 $(\mathrm{E})$, 脆弱性 $(\mathrm{V})$, レジリエンス $(\mathrm{Re})$ の 3 つの要 素を組み合わせた自然災害リスク（総合評価）の算定結果を 図 5 に示す。また, 曝露量, 脆弱性, レジリエンス, 自然 災害リスクの都道府県ごとの指標一覧を表 3 に示す。表中 の（）表記は順位を表す.

自然災害リスクの高いのは, 高い順に富山県, 福井県, 大阪府, 神奈川県, 岐阜県, 大分県, 埼玉県, 長野県, 兵庫 県, 三重県となっている。逆に, 自然災害リスクの低いのは, 低い順に佐賀県, 宮崎県, 島根県, 沖縄県, 青森県, 鳥取県, 岡山県, 香川県, 岩手県, 高知県となっている.

都道府県で最も顕著な例としては東京都が挙げられる．東 京都は曝露量が全国第一位, 脆弱性も全国第二位であるが, レジリエンスの数值が高い（全国第一位）ためにトータルの 自然災害リスクとしては全国で第12位となっている。この 傾向は世界リスク報告書2016に記載されている日本の傾向 とも合致する。すなわち，日本は自然災害に遭遇する確率は 非常に高いが, 社会インフラが整備されていれば壊滅的な被 害を軽減できるという切り口と一致している，具体的には， 日本は自然災害に遭遇する可能性は全世界で第4位と高い が, 極めて高いインフラの充実度, 対処能力や適応能力の高 さなどから全体の17位まで総合順位を下げている。この傾 向は, 大都市圈をかかえる大阪府（曝露量は全国第2位, 脆 弱性は全国第10位,レジリエンスは全国第3 位), 神奈川県 (曝 露量は全国第5位，脆弱性は全国第6位，レジリエンスは全 国第4位), 愛知県 (曝露量は全国第9位, 脆弱性は全国第4位, レジリエンスは全国第5位）なども同じ傾向にある.

一方，自然災害リスク指標で大都市圈以外で上位に位置す るのは, 富山県, 福井県, 岐阜県, 大分県などである.これ らの都道府県の特徴は, 曝露量だけが高く, 脆弱性やレジリ エンスはそれほど高くないことである，曝露量が高い理由 は, 海溝型地震による被災人口は少ないものの, 多くの活断 層があるため活断層密度が関係していると考えられる。自然

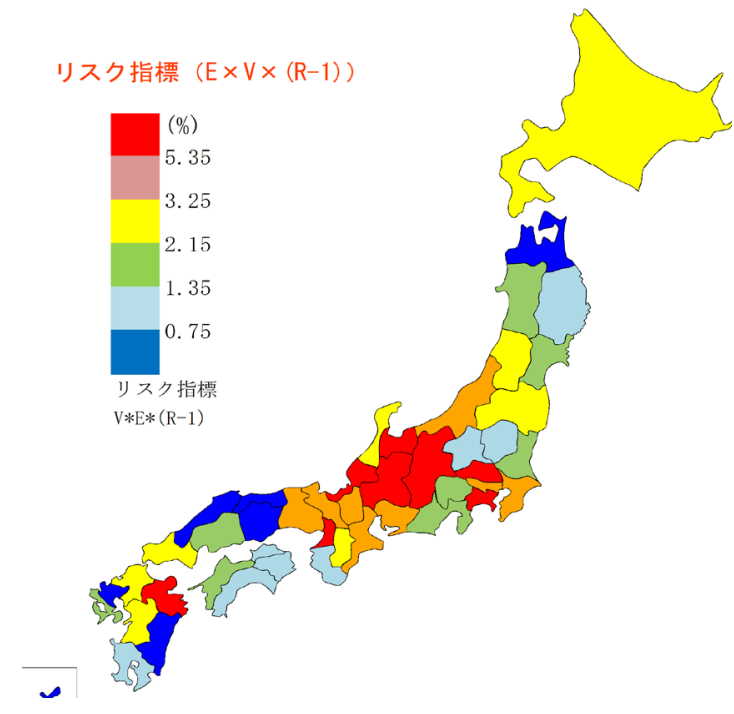

図5 自然災害リスク(総合指標)の都道府県分布 [6] 
表3 自然災害リスク指標と各要因の值および順位 [6]

\begin{tabular}{|c|c|c|c|c|}
\hline & 暴露量 $(\mathrm{E})$ & 脆弱性(V) & $\begin{array}{c}\text { レジリエンス } \\
(1-\mathrm{R})\end{array}$ & $\begin{array}{c}\text { Risk }=\mathrm{E} * \mathrm{~V} * \\
(1-\mathrm{R}) * 100\end{array}$ \\
\hline 01 北海道 & $0.08336(32)$ & $0.43810(1)$ & $0.66319(41)$ & $2.42197(21)$ \\
\hline 02青森県 & $0.03133(44)$ & $0.15216(45)$ & 0.88248 (3) & $0.42065(43)$ \\
\hline 03岩手県 & $0.04153(41)$ & $0.22037(30)$ & $0.86030(5)$ & $0.78742(39)$ \\
\hline 04宮城県 & $0.08365(31)$ & $0.26531(14)$ & $0.73955(26)$ & $1.64132(31)$ \\
\hline 05秋田県 & \begin{tabular}{|l}
$0.08201(34)$ \\
\end{tabular} & \begin{tabular}{|l|}
$0.20258(34)$ \\
\end{tabular} & \begin{tabular}{|l|l|l}
0.89419 & $(2)$ \\
\end{tabular} & $1.48556(32)$ \\
\hline 06山形県 & $0.13755(24)$ & 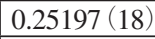 & \begin{tabular}{|lll}
0.84399 & $(8)$ \\
\end{tabular} & $2.92515(20)$ \\
\hline 07福島県 & $0.08332(33)$ & $\begin{array}{|ll|}0.30295(8) \\
\end{array}$ & $\begin{array}{l}0.92470(1) \\
\end{array}$ & $2.33400(22)$ \\
\hline 08茨城県 & $0.11631(25)$ & $0.22852(26)$ & $0.74989(24)$ & $1.99318(25)$ \\
\hline 09栃木県 & $0.04054(42)$ & $0.24562(19)$ & $\begin{array}{lll}0.86395(4) \\
\end{array}$ & $0.86026(37)$ \\
\hline 10 群馬県 & $9(40)$ & & 0.80119 (13) & $66(36)$ \\
\hline 11 埼玉県 & $0(11)$ & $7(9)$ & $50(37)$ & $76(7)$ \\
\hline 12 千葉県 & $0.25762(12)$ & $59(17)$ & $0.60401(42)$ & $4(14)$ \\
\hline 13東京都 & $0.54557 \quad(1)$ & $0.39118 \quad(2)$ & $0.23917(47)$ & $0(12)$ \\
\hline 14神奈川県 & $0.45459(5)$ & $58(6)$ & $0.50651(44)$ & $39 \quad(4)$ \\
\hline 15 新潟県 & $0.16590(19)$ & 6(11) & $0.73438(30)$ & $1(15)$ \\
\hline 16富山県 & $38(6)$ & $(22)$ & $0.74244(25)$ & $30(1)$ \\
\hline 17石川県 & $1(21)$ & $3(29)$ & $0.72884(33)$ & $88(23)$ \\
\hline 18 福井県 & 52(3) & $5(38)$ & $0.82837(11)$ & $14(2)$ \\
\hline 19山梨県 & $0.14140(22)$ & 0.17 & $0.72925(32)$ & $61(27)$ \\
\hline 20 長野県 & $0.20483(15)$ & 0.34156(3) & $0.76889(21)$ & $37(8)$ \\
\hline 21 岐阜県 & $0.36326(7)$ & $0.27764(13)$ & $0.70974(36)$ & 7.15803 \\
\hline 22静岡県 & $0.18978(16)$ & $0.23415(23)$ & $0.38024(46)$ & $1.68973(29)$ \\
\hline 23 愛知県 & $0.28532(9)$ & $0.33435(4)$ & $0.53627(43)$ & $5.11584(11)$ \\
\hline 24三重県 & $0.23961(14)$ & \begin{tabular}{|lll}
$0.30895 \quad(7)$ \\
\end{tabular} & \begin{tabular}{|l|l}
$0.70070(38)$ \\
\end{tabular} & $5.18709(10)$ \\
\hline 25 滋賀県 & $0.29962(8)$ & $0.20609(32)$ & $0.67060(39)$ & $4.14101(13)$ \\
\hline 26京都府 & $0.27141(10)$ & $0.18440(37)$ & $0.72571(34)$ & $3.63213(16)$ \\
\hline 27 大阪府 & $0.53714(2)$ & $0.30148(10)$ & $0.46232(45)$ & $7.48673(3)$ \\
\hline 28 兵庫県 & $0.25044(13)$ & $0.31881 \quad(5)$ & $0.66967(40)$ & $5.34677 \quad(9)$ \\
\hline 29奈良県 & $0.15942(20)$ & $0.23407(24)$ & $0.79859(14)$ & $2.97995(17)$ \\
\hline 30和歌山県 & $0.06027(36)$ & $0.22961(25)$ & $0.73589(28)$ & $1.01838(35)$ \\
\hline 31 鳥取県 & $0.04486(38)$ & $0.15493(44)$ & \begin{tabular}{|l|l|}
$0.84153(9)$ \\
\end{tabular} & $0.58484(42)$ \\
\hline 32 島根県 & $0.02395(45)$ & $0.14852(46)$ & $0.78892(16)$ & $0.28058(45)$ \\
\hline 33 岡山県 & $0.03919(43)$ & $0.24503(20)$ & $0.77716(18)$ & $0.74622(41)$ \\
\hline 34広島県 & $0.08500(30)$ & $0.26404(15)$ & $0.73534(29)$ & $1.65032(30)$ \\
\hline 35 山口県 & (17) & 0.21 & $0.73305(31)$ & $9(18)$ \\
\hline 36 徳島県 & $4(27)$ & 0.16 & $0.71630(35)$ & $50(33)$ \\
\hline 37香川県 & & & \begin{tabular}{|l|l}
$0.77018(20)$ \\
\end{tabular} & $3(40)$ \\
\hline 38愛媛県 & & 0.17 & 0.73 & 1.78 \\
\hline 39高知県 & $3(39)$ & $0.24502(21)$ & $0.79025(15)$ & $0.83123(38)$ \\
\hline 40 福岡県 & $0.16967(18)$ & $0.20592(33)$ & $0.83898(10)$ & $2.93121(19)$ \\
\hline 41 佐賀県 & $0.00872(47)$ & $0.22318(28)$ & $0.81070(12)$ & $0.15786(47)$ \\
\hline 42 長崎県 & 0.09609 (29) & $0.22840(27)$ & $0.77215(19)$ & $1.69454(28)$ \\
\hline 43 熊本県 & $0.11367(26)$ & $0.25892(16)$ & $0.78072(17)$ & $2.29782(24)$ \\
\hline 44大分県 & 0.50049 (4) & $0.18630(36)$ & $0.76580(22)$ & $7.14028(6)$ \\
\hline 45宮崎県 & $0.01983(46)$ & $0.18270(39)$ & $0.75609(23)$ & $0.27390(46)$ \\
\hline 46鹿児島県 & $0.06989(35)$ & $0.20070(35)$ & $0.85106(7)$ & $1.19370(34)$ \\
\hline 47 沖縄県 & $0.10144(28)$ & $0.03463(47)$ & $\begin{array}{lll}0.85115(6) \\
\end{array}$ & $0.29900(44)$ \\
\hline
\end{tabular}

災害リスク指標の低いのは佐賀県, 宮崎県, 島根県, 沖縄県 などであるが, これらの県は曝露量や脆弱性が低く，しかも レジリエンスも高くないことが特徴である。

\section{4. おわりに}

本稿ではインフラレジリエンスや国土強勒化などで頻出す る自然災害リスクに関連する用語である曝露量, 脆弱性, レジ リエンスについて概説した。 この内容が一般市民にとって 難解な専門用語の理解に少しでも役に立てれば幸いである.

\section{参 考 文 献}

[1] UNU-EHS (The United Nations University, the Institute for Environment and Human Security): World Risk Report 2016. https://collections.unu.edu/eserv/UNU:5763/ WorldRiskReport2016_small_meta.pdf (2021.07.16閲覧).

[2] 伊藤和也, 菊本統, 下野勘智, 大里重人, 稲垣秀輝, 日下部治：我が国の自然災害に対するリスク指標の変 遷と諸外国との比較, 自然災害科学, 36 (1), pp.73-86, 2017.

[3] 下野勘智, 菊本統, 伊藤和也, 大里重人, 稲垣秀輝, 日下部治：自然災害に対する全国47都道府県のリス ク指標の試算と考察, 土木学会論文集 F6 (安全問題), 72(1), pp.1-10, 2016.

[4] (公社) 地盤工学会関東支部地盤リスクと法訴訟等の 社会システムに関する研究委員会：自然災害に対するリス ク指標 GNS [2015 年版], 2015.

[5］（公社）地盤工学会関東支部地盤リスクと法訴訟等の 社会システムに関する研究委員会自然災害に対する 安全性指標 $(\mathrm{GNS})$ の開発とその活用に関する研究委 員会：自然災害に対するリスク指標 GNS「2017年版」, 2017.

[6] 保田敬一, 白木渡: 橋梁長寿命化修繥計画における 自然災害リスクの反映方法の提案, 土木学会論文集 F6 (安全問題)，75(2)，pp.I_137-I_156, 2019.

［7］保田敬一, 白木渡：橋梁長寿命化修繥計画に招ける 自然災害リスク指標に関する一考察，第9回構造物の 安全性・信頼性に関する国内シンポジウム（JCOSSAR 2019）論文集，9，OS16-3A，pp.73-80， 2019.

(2021年7月 29 日受理)

著 者紹介

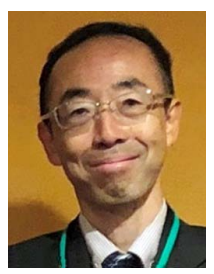

保田 敬一(正会員)

1983 年鳥取大学工学部土木工学科卒業, 1999年 鳥取大学大学院工学研究科博士後期課程修了, 現在, 一般社団法人国際建設技術協会に所属, 技術士（建設部門，情報工学部門，総合技術監 理部門). 博士 (工学)。この間, 橋梁の計画 · 設計・施工・維持管理業務, ソフトコンピューティング (ニューラ ルネットワーク, GA, プロダクトモデルなど）抢よび感性工学 に係る研究に従事, 所属学会は感性工学会, 土木学会. 2003 年〜 現在日本感性工学会論文編集委員会編集委員. 